\title{
ANALISIS PENERAPAN SISTEM PENGENDALIAN INTERNAL PEMBERIAN KREDIT USAHA KECIL MENENGAH PADA PT. BANK TABUNGAN NEGARA CABANG TERNATE
}

\author{
Mulyati Primagama ${ }^{1}$, Grace B. Nangoi ${ }^{2}$, Treesje Runtu ${ }^{3}$ \\ 1,2,3 Jurusan Akuntansi, Fakultas Ekonomi dan Bisnis, Universitas Sam Ratulangi, Jl.Kampus Bahu, Manado, \\ 95115, Indonesia
}

E-mail : Primagamamulyati@yahoo.com

\begin{abstract}
In granting loans bank has a risk of bad credit. Internal control is the methods used to coordinate a company to achieve the corporate goals which include organizational structure division of authority, established procedures, and healthy practices. this is done to minimize the risk of bad credit. Banks must be able to detect bad loans first so as not to cause bank losses. The direction of this research is to find out the application of internal control based on credit at PT. Bank Tabungan Negara Ternate. The research method used in this research is a qualitative method. The results of research related to the internal receivable control system has been carried out well in accordance with the elements of internal control of COSO including the control environment, risk assessment, control activities, information and communication, monitoring.
\end{abstract}

Keywords: Internal Control, Granting Credit

\section{PENDAHULUAN}

Bank merupakan suatu organisasi yang mempunyai peran sebagai penghubung antara masyarakat yang mempunyai dana dengan yang membutuhkannya, dan juga sebagai instansi yang berguna untuk menaikkan taraf hidup orang banyak. Bank memiliki banyak produk dan jasa seperti tabungan, giro, deposito, kredit, dan lain-lain. Kredit adalah salah satu dari beberapa kegiatan usaha perbankan yang berkaitan dengan pinjaman dan beresiko tinggi, sebab kredit adalah aset bank yang ada di pihak luar bank. Bank Tabungan Negara adalah salah satu perbankan yang menyediakan fasilitas kredit bagi masyarakat. Salah satu jenis kredit yang ada pada Bank Tabungan Negara yaitu kredit usaha kecil menengah (UKM). Kredit usaha kecil menengah yaitu kredit yang diberikan kepada para pengusaha skala kecil hingga menengah untuk membantu mengembangkan usahanya. Pemberian kredit kepada pelaku usaha kecil menengah mempunyai resiko tidak terbayarnya kembali kredit tersebut. Hal itu bisa timbul dikarenakan kurang tepatnya analisis dalam pemberian persetujuan kredit.

Pentingnya peranan sistem pengendalian internal dikarenakan dengan penerapan sistem pengendalian internal yang memadai, dapat menjamin mutu kelayakan operasi yang dijalankan. Dengan adanya pengendalian dalam suatu entitas maka diinginkan agar seluruh kegiatan bisa bergerak selaras dengan apa yang telah ditetapkan. Jadi pengendalian internal dibutuhkan seperti satu perangkat yang dapat mendukung dalam mengendalikan kegiatan perkreditan yang akan berpengaruh pada apa yang menjadi sasaran entitas atau organisasi. Resiko kerugian di masa yang akan datang dapat diperkecil jika ditaatinya prosedur pemberian kredit, adanya sumber daya manusia yang berkualitas dan pengawasan secara berkala setelah diberikannya kredit. Pengendalian internal tidak hanya dari sisi penjagaan saja, tetapi juga agar segala usaha di bidang perkreditan tersebut bisa berjalan secara efektif dan efisien. Untuk peningkatan efisiensi dan pengamanan terhadap aset bank tersebut, tentunya dibutuhkan pengaturan administrasi perkreditan dengan baik terlebih dahulu agar dapat diandalkan. 


\section{TINJAUAN PUSTAKA}

Pengendalian Internal. Pengendalian internal ialah pemilihan segala rencana organisasional, metode, dan pengukuran oleh suatu entitas guna melindungi harta kekayaannya, mengecek ketepatan dan keandalan data akuntansi usaha tersebut, meningkatkan efisiensi operasional, membantu ditaatinya kebijakan manajerial yang sudah ditentukan (Diana dan setiawati, 2011:82).

Unsur-Unsur Pengendalian Internal. Dalam dokumen the commite of sponsoring organization (COSO, 2013:4) menyebutkan 5 unsur pokok dari suatu sistem pengendalian internal yang efektif, yaitu sebagai berikut.

1. Lingkungan pengendalian (control environment), adalah membuat kondisi pengendalian dalam organisasi dan mempengaruhi kesadaran anggota organisasi pengendalian.

2. Penilaian resiko (risk assessment), merupakan identifikasi, analisis dan pengelolaan resiko entitas yang berkaitan dengan penyusunan laporan keuangan sesuai dengan prinsip yang berlaku umum.

3. Aktivitas pengendalian (control activities), yaitu dibuatnya prosedur dan kebijakan guna memberikan keyakinan bahwa petunjuk yang dibuat oleh manajemen dilaksanakan.

4. Informasi dan komunikasi, merupakan sistem akuntansi yang dibuat untuk mengidentifikasi, menggolongkan, menganalisis, mencatat dan melaporkan transaksi suatu entitas, menyelenggarakan pertanggungjawaban kekayaan dan utang entitas tersebut.

5. Pemantauan, adalah cara monitoring atau pengecekan secara rutin terhadap kinerja sistem pengendalian internal.

Adapun menurut (Mulyadi, 2014:164) Unsur utama pengendalian internal adalah sebagai berikut:

1. Struktur organisasi yang membagi tugas fungsional secara jelas.

2. Sistem wewenang dan metode pencatatan yang membuat perlindungan yang memadai terhadap kekayaan, kewajiban, penerimaan, dan beban.

3. Praktek pengendalian yang baik.

4. Karyawan yang mutunya sesuai dengan tanggung jawabnya.

Tujuan Sistem Pengendalian Internal. Tujuan pengendalian internal adalah sebagai berikut (Tuanakotta, 2014:127).

1. Meyakinkan pencatatan akuntansi yang tepat dan dapat dipercaya.

2. Melindungi aset.

3. Membuat para karyawan mengikuti kebijakan perusahaan.

4. Menaikkan efisiensi operasional.

Pengertian Kredit. Menurut Undang-Undang perbankan Nomor 10 Tahun 1998, pengertian kredit adalah penyediaan uang yang didasarkan pada kesepakatan pinjam meminjam antara bank dengan pihak lain mewajibkan pihak peminjam untuk melunasi utangnya setelah jangka waktu tertentu dengan pemberian bunga. Dari rumusan tersebut dapat diketahui bahwa kredit itu merupakan kesepakatan pinjam meminjam uang antara bank sebagai kreditur dengan nasabah sebagai debitur. Selain itu, sistem pemberian kredit didasarkan juga atas keyakinan bank atas kemampuan debitur untuk membayar kredit. Untuk memperoleh keyakinan tersebut, maka sebelum memberikan kredit, bank harus melakukan penilaian dengan seksama.

Unsur-Unsur Kredit. Unsur-unsur yang kredit adalah sebagai berikut (Kasmir, 2012:114) : (1) Kepercayaan; (2) Persetujuan; (3) Tenggang waktu; (4) Resiko; dan (5) Timbal balik. 
Tujuan dan Fungsi Kredit. Dalam memberikan kredit terdapat beberapa tujuan yang akan dicapai sesuai dengan apa misi entitas. Dalam pengaplikasiannya pemberian kredit bertujuan sebagai berikut (Kasmir, 2012:115): (1) mendapatkan keuntungan; (2) mendukung usaha nasabah; dan (3) mendukung pemerintah.

Selain mempunyai tujuan pemberian kredit juga mempunyai fungsi yaitu:

1. Menambah daya guna uang.

2. Meningkatkan penyebaran dan lalu lintas uang.

3. Menaikkan persebaran barang.

4. Menjadi media stabilitas ekonomi.

5. Menaikkan keinginan berusaha.

6. Menambah pemerataan penerimaan.

7. Membangun koneksi internasional.

Adapun berdasarkan (Hasibuan 2008:88) terdapat tujuh tujuan dari penyaluran kredit yaitu:

1. Mendapatkan penerimaan bank dari bunga kredit.

2. Menggunakan dan memanfaatkan dana kredit.

3. Menjalankan aktivitas operasional bank.

4. Mencukupi permintaan kredit masyarakat.

5. Melancarkan pembayaran.

6. Menaikkan modal kerja perusahaan.

7. Menambah penerimaan dan kesejahteraan masyarakat.

Menurut (Ismail, 2010:96) fungsi kredit adalah sebagai berikut:

1. Menaikkan arus tukar menukar barang dan jasa.

2. Sebagai alat yang dipakai untuk memanfaatkan idle fund.

3. Menciptakan alat pembayaran yang baru.

4. Sebagai media pengendali harga.

5. Untuk menaikkan mafaat ekonomi yang ada.

Jenis-Jenis Kredit. Jenis-jenis kredit menurut (Ikatan Bankir Indonesia, 2014:27).

1. Kredit konsumer. Adalah jenis kredit yang dialokasikan untuk penggunaan dana bersifat konsumtif atau digunakan sendiri seperti pembelian rumah dan lain sebagainya.

2. Kredit ritel. Yaitu kredit yang dialokasikan kepada perseorangan maupun badan usaha dan difungsikan untuk menjalankan aktivitas usaha.

3. Kredit wholesale, Jenis ini hampir sama dengan kredit ritel, tetapi mempunyai ukuran kredit yang lebih besar.

Prinsip-Prinsip Pemberian Kredit. Adapun menurut (Ikatan Bankir Indonesia, 2014:114) prinsip pemberian kredit yaitu:

1. Character (Watak). Adalah menilai karakter calon debitur sehingga dapat diketahui bahwa debitur tersebut dapat dipercaya,dan tidak memberikan kesulitan pada pihak bank di masa yang akan datang.

2. Capacity (Kemampuan). Merupakan pengukuran bank terhadap kemampuan calon debitur dalam menjalankan usahanya, sehingga bank yakin bahwa kredit yang diberikan untuk membiayai usaha tersebut bisa dikelola dengan benar.

3. Capital (Modal). Adalah penilaian bank terhadap laporan keuangan peminjam, termasuk arus kas, baik di periode sebelumnya dan juga proyeksi di masa depan, sehingga bisa dilihat kesanggupan modal debitur untuk membiayai usaha tersebut.

4. Condition of Economic (Kondisi Perekonomian). Merupakan penilaian bank terhadap kondisi pasar didalam dan diluar negeri, pada waktu lalu dan juga masa yang akan datang, 
sehingga dapat diketahui peluang pemasaran dari hasil usaha debitur yang ditunjang oleh kredit dari bank.

5. Collateral (Agunan). Yaitu penilaian bank pada jaminan yang akan diberikan oleh calon debitur. Jaminan ini busa berupa benda berwujud maupun tidak berwujud yang diserahkan oleh calon debitur kepada pihak bank sebagai jaminan untuk melunasi kredit.

Prosedur Pemberian Kredit. Menurut (Kasmir, 2014:101) prosedur pemberian kredit secara umum adalah sebagai berikut:

1. Pengajuan berkas. Yaitu pemohon kredit menyampaikan permohonan yang dituangkan dalam suatu proposal. Kemudian dilampiri dengan berkas-berkas yang dibutuhkan dalam permohonan kredit.

2. Pemeriksaan berkas pinjaman. Bertujuan untuk mengetahui kelengkapan dan kebenaran berkas pinjaman. Pemberian kredit dapat dilanjutkan ketika berkas pinjaman telah lengkap dan jika berkas tersebut belum lengkap maka akan diberikan surat pemberitahuan. Apabila berkas tidak dilengkapi maka akan dibatalkan.

3. Wawancara pertama. Wawancara ini dilakukan untuk melihat keinginan calon debitur.

4. On the spot. Yaitu langkah pengecekan ke objek yang akan dijadikan usaha dan jaminan.

5. Wawancara kedua. Dalam langkah ini terdapat kegiatan penyempurnaan berkas, jika ada kekurangan disaat setelah dilakukan pemeriksaan langsung ke lapangan.

6. Keputusan Kredit. Yaitu langkah penentuan apakah kredit tersebut akan diberikan atau tidak, jika kredit tersebut diterima maka administrasi yang akan disiapkan sebagai berikut : (a) besarnya uang yang akan diterima; (b) jangka waktu; dan (c) dan semua beban yang harus dibayar.

7. Pengesahan perjanjian kredit. Proses ini adalah tahap selanjutnya dari keputusan kredit, maka sebelum diberikan calon debitur harus menandatangani kesepakatan kredit, mengikat agunan dan surat persetujuan yang dianggap perlu. Penandatanganan tersebut dilaksanakan antara bank dan calon debitur atau dengan menggandeng notaris.

8. Pelaksanaan Kredit. Pelaksanaan kredit dilakukan sesudah surat-surat yang di telah ditandatangani butuhkan dan membuka rekening tabungan di bank tersebut.

9. Distribusi dana kredit. Adalah pencairan uang dari rekening yang dapat diambil sekaligus atau bertahap sesuai dengan ketentuan.

Usaha Kecil Menengah. Menurut Undang-Undang No 20 tahun 2008, bahwa yang termasuk dalam usaha kecil, yaitu pelaku usaha yang mempunyai kekayaan bersih antara 50500 juta Rupiah (tidak termasuk tanah dan bangunan). Yang termasuk dalam usaha menengah yaitu usaha yang memiliki kekayaan lebih dari 500 juta Rupiah sampai 10 miliar Rupiah (tidak termasuk bangunan dan tanah).

\section{METODE PENELITIAN}

Jenis Penelitian. Jenis penelitian yang dipakai adalah deskriptif kualitatif dimana peneliti akan mendeskripsikan permasalahan yang berkaitan dengan apa yang akan diteliti dalam bentuk uraian kalimat berdasarkan keterangan-keterangan yang diperoleh dari pihakpihak yang berhubungan langsung dengan penelitian.

Tempat dan Waktu Penelitian. Penelitian dilakukan di PT. Bank Tabungan Negara Cabang Ternate tepatnya berada di Jl. Zainal Abidin Syah Ternate, Maluku Utara. Waktu penelitian dilakukan pada bulan Juli 2018 hingga selesai. 


\section{Jenis, sumber, dan metode pengumpulan data}

Jenis Data. Penelitian ini menggunakan data kualitatif yang berupa sejarah, visi misi perusahaan, syarat-syarat pemberian kredit, prosedur pemberian kredit dan pengendalian kredit yang di PT. Bank Tabungan Negara Ternate.

Sumber Data. Dalam penelitian ini menggunakan data primer sebagai sumber dalam pengambilan data didapat secara langsung oleh penulis terhadap pegawai PT. Bank Tabungan Negara Ternate di bidang kredit dan di bidang pengawasan kredit melalui wawancara untuk mendapatkan informasi yang diperlukan dalam penelitian ini berupa prosedur pengendalian kredit.

Metode Pengumpulan Data. Metode pengumpulan data adalah metode paling penting dalam penelitian dikarenakan tujuan pokok dari penelitian adalah memperoleh data (Sugiyono, 2013:224). Adapun metode pengumpulan data yang digunakan untuk memperoleh data dan informasi yang berkaitan dalam penelitian ini sebagai berikut :

1. Dokumentasi. Yaitu dengan meminta beberapa dokumen yang dibutuhkan kepada pihak dan terkait dengan penelitian seperti sejarah, visi misi dan syarat-syarat dalam mengajukan kredit. Data dalam penelitian ini adalah dokumen resmi dari bank. Pengumpulan data dilakukan dengan mencari data mengenai hal-hal yang diteliti seperti sejarah, visi misi perusahaan dan formulir pemberian kredit. Data dalam penelitian ini adalah dokumen resmi dari bank.

2. Wawancara. Yaitu mendapatkan data yang dibutuhkan dengan cara mewawancarai pegawai bagian kredit dan pengawasan kredit PT Bank Tabungan Negara Ternate mengenai prosedur pemberian kredit dan pengendalian kredit.

Metode Analisis Data. Analisis deskriptif merupakan metode yang digunakan untuk menganalisa data dalam penelitian ini. Berikut adalah beberapa langkah analisis dimulai dari mengumpulkan dan menyaring keterangan-keterangan yang diperoleh secara menyeluruh, kemudian diuraikan sehingga diperoleh gambaran prosedur dan pengendalian internal pemberian kredit di PT. Bank Tabungan Negara Ternate.

\section{HASIL PENELITIAN DAN PEMBAHASAN}

\subsection{Hasil Penelitian}

PT. Bank Tabungan Negara adalah salah satu perbankan milik negara yang merupakan badan usaha milik negara (BUMN). Yang mempunyai program unggulan di bidang perreditan terutama kredit perumahan. Prosedur pemberian kredit merupakan hal yang penting dalam pengendalian kredit . Tujuannya agar mempermudah bank untuk melakukan penilaian terhadap resiko kredit. Berikut adalah prosedur pemberian kredit pada Bank Tabungan Negara.

1. Permohonan. Calon debitur mengajukan permohonan kredit dengan melampirkan syaratsyarat administrasi yang telah ditentukan. Syarat-syarat administrasi tersebut berupa 1) KTP pemohon, 2) akte pendirian perusahaan sampai dengan akte perubahan terakhir, 3) surat keterangan penghasilan, 4) NPWP (Nomor Pokok Wajib Pajak), 5) Perijinan usaha, 6) Legalitas tempat usaha, 7) Copy rekening/tabungan, 8) Legalitas agunan, 9) SITU (Surat Izin Tempat Usaha), 10) SIUP (Surat Izin Usaha Perdagangan), 11) TDP (Tanda Daftar Perusahaan). Jika syarat-syarat diatas belum lengkap maka calon debitur akan diberikan surat pemenuhan berkas untuk melengkapi dokumen-dokumen tersebut dan jika syarat-syarat tersebut telah lengkap maka pihak bank akan mengeluarkan permohonan izin prinsip.

2. Wawancara. Wawancara dilakukan antara petugas bank dan calon debitur saat calon debitur telah melengkapi dokumen administrasi. 
3. Analisa kredit. Dalam menganalisis kemampuan calon debitur pihak bank sudah menggunakan penilaian dengan prinsip 5C yang disebut dengan paket analisa kredit (PAK) yaitu:

a. Aspek Keuangan. Cara bank menganalisa aspek keuangan dengan melihat laporan keuangan yang disajikan dengan melakukan pengukuran rasio likuiditas, rasio solvabilitas, rasio profitailitas.

b. Aspek Manajemen. Cara bank menganalisa aspek manajemen yaitu dengan BI Cheking yang sekarang digantikan dengan SLIK (Sistem Layanan Informasi Keuangan) untuk melihat riwayat kredit calon debitur.

c. Aspek Jaminan. Pihak bank akan mengecek langsung jaminan yang diberikan oleh calon debitur, syarat yang dapat dijadikan sebagai jaminan yaitu sebagai berikut: (1) Nilai jaminan lebih besar dari nilai kredit; (2) Jaminan tidak dalam sengketa; dan (3) Jaminan adalah milik sendiri.

d. Aspek Legalitas. Cara bank menganalisa aspek legalitas adalah dengan melihat dokumen-dokumen seperti, Surat Izin Tempat Usaha (SITU), Tanda Daftar Perusahaan (TDP), Nomor Pokok Wajib Pajak (NPWP), Surat Izin Usaha Perdagangan (SIUP).

e. Aspek Pemasaran. Cara bank menganalisis aspek pemasaran untuk melihat kemampuan perusahaan untuk membayar yaitu dengan melihat tingkat penjualan yang terdapat di laporan keuangan.

Setelah analisa resiko kredit tersebut dirasa cukup maka akan dikeluarkan Surat Persetujuan Pemberian Kredit (SP2K).

1. OTS (On The Spot). Setelah keaslian dokumen dan proses wawancara selesai pihak bank melakukan kunjungan langsung untuk melihat tempat usaha calon debitur serta menganalisa aspek agunan.

2. Legal meeting. Memastikan legalitas berkas foto copy pemohon sudah sesuai dengan aslinya dan tidak jatuh tempo.

3. Akad kredit. Akad kredit dilakukan bersama notaris. Notaris tersebut akan memastikan dokumen kredit sesuai dengan SP2K.

4. Monitoring. Monitoring dilakukan satu tahun pertama setelah itu monitoring akan dilakukan setiap 3 bulan sekali sampai dengan lunasnya kredit tersebut.

\subsection{Pembahasan}

Lima unsur pengendalian internal menurut COSO yang terkait dalam pemberian kredit, berdasar data yang diperoleh dapat diuraikan sebagai berikut :

1. Lingkungan Pengendalian

a. Integritas dan Nilai Etika. Manajemen dan karyawan lainnya lainnya telah menunjukkan sikap terhadap integritas dan nilai-nilai etika dapat dilihat dari kode etik yang ditetapkan oleh manajemen dan dikomunikasikan ke seluruh karyawan agar dilaksanakan.

b. Independensi Manajemen. Dewan direksi sudah menunjukkan independensi dari manajemen dengan tidak memihak kepada siapapun.

c. Menetapkan Struktur, Jalur pelaporan dan Tanggung Jawab. Bank mempunyai struktur organisasi yang jelas dan menjalankan tugas dan wewenang sesuai dengan job desc masing-masing. Pada transaksi pemberian kredit setiap proses dari awal sampai akhir dilaksanakan oleh bagian yang berwenang mengotorisasi proses pemberian kredit.

d. Organisasi Memastikan Karyawan Bertanggung Jawab Terhadap Tugas dan Pengendalian Internal. Setiap karyawan mendapat email dan memo berupa kata-kata 
peringatan yang disebut early warning system tentang tanggung jawab karyawan setiap bulannya dan diadakan sosialisasi pengendalian internal untuk karyawan.

e. Menunjukkan Komitmen Terhadap Kompetensi. Bank melakukan pelatihan rutin kepada karyawan dan memberikan promosi jabatan kepada karyawan telah menjalankan tugas dan tanggung jawab dan memberikan promosi jabatan kepada karyawan telah menjalankan tugas dan tanggung jawab dengan baik.

2. Penilaian Resiko.

a. Menetapkan Tujuan Yang Sesuai Untuk Memungkinkan Identifikasi dan Penilaian Resiko. Karyawan yang menangani proses pemberian kredit mengetahui dengan jelas syarat-syarat serta data kredit serta data kredit yang harus dipenuhi calon debitur.

b. Mengidentifikasi dan Menganalisa Resiko. Bank melakukan analisis dengan menerapkan analisis 5C dan melakukan legal meeting untuk memastikan berkas sudah sesuai dengan aslinya dan tidak jatuh tempo sebelum memberikan kredit.

c. Mempertimbangkan Potensi Kecurangan. Bank melakukan pemeriksaan langsung ke lapangan terhadap jaminan untuk meminimalisir resiko kecurangan.

d. Mengidentifikasi dan Menilai Perubahan yang Signifikan. Adanya evaluasi kebijakan prosedur dan manajemen perkreditan secara menyeluruh.

3. Aktivitas Pengendalian

a. Menetapkan dan Mengembangkan Kegiatan dalam Pengendalian Internal. Adanya pemisahan tugas yang memadai terlihat dari adanya pembagian tugas yang menangani permohonan, analisis dan administrasi kredit.

b. Menentukan dan Membangun Pengendalian Umum Atas Teknologi. Dalam menganalisis rekam kredit calon debitur pihak bank telah menggunakan SLIK (Sistem Layanan Informasi Kredit.

4. Informasi dan Komunikasi.

a. Menghasilkan dan Menggunakan informasi yang Berkualitas dan yang Relevan. Bank memperoleh informasi yang berkualitas dan relevan mengenai kebijakan-kebijakan kredit terbaru dari Bank Indonesia dan Otoritas Jasa Keuangan.

b. Mengkomunikasikan Informasi Termasuk Tujuan dan Tanggung Jawab Untuk Pengendalian Internal Secara Internal. Bank rutin melaksanakan sosialisasi kepada karyawan tentang pengendalian internal untuk mendukung berjalannya fungsi pengendalian internal dengan baik.

c. Melakukan Komunikasi Kepada Pihak Eksternal. Pihak bank selalu memberitahukan setiap program dan produk baru yang ada di bank kepada mayarakat untuk menarik nasabah baru.

5. Monitoring/ Pemantauan. Aktivitas pemantauan yang dilakukan oleh pihak bank secara berkala sudah diterapkan dengan baik yaitu setiap tiga bulan sekali.

\section{KESIMPULAN DAN SARAN}

\subsection{Kesimpulan}

Berdasarkan informasi yang telah didapat dan analisis data yang dilakukan maka ditarik kesimpulan bahwa prosedur pemberian kredit pada Bank Tabungan Negara telah dilakukan dengan baik karena pihak bank telah melaksanakan prosedur pemberian kredit yang terdiri dari: 1) tahap permohonan, 2) wawancara, 3) OTS (On The Spot), 4) analisa kredit, 5) legal meeting, 6) akad kredit, 7) monitoring. Pengendalian Intern yang diterapkan pada Bank BTN Cabang Ternate sudah berjalan baik berdasarkan standar pengendalian internal oleh COSO meliputi lingkungan pengendalian, penilaian resiko, aktivitas pengendalian, Informasi dan komunikasi, dan aktivitas pemantauan atau monitoring. 


\subsection{Saran}

Berdasarkan kesimpulan diatas, penulis menyarankan agar perusahaan tetap mempertahankan dan terus meningkatkan kualitas sistem pengendalian internal pemberian kredit sesuai dengan perkembangan perkreditan di Indonesia.

\section{DAFTAR PUSTAKA}

COSO. 2013. Internal Control-Integrated Framework: Executive Summary. Durham. North Carolina.

Diana, A. dan L. Setiawati. 2011. Sistem Informasi Akuntansi. Penerbit Andi. Yogyakarta.

Hasibuan, M. 2008. Dasar-dasar Perbankan. PT. Grafindo. Jakarta

Ismail. 2010. Manajemen Perbankan: Dari teori menuju aplikasi. Kencana. Jakarta.

Ikatan Bankir Indonesia. 2014. Mengelola Kredit Secara Sehat. Edisi ke-1. PT Gramedia Pustaka Utama. Jakarta

Kasmir. 2012. Dasar-Dasar perbankan. Edisi Revisi. PT. RajaGrafindo Persada. Jakarta. . 2014. Dasar-Dasar perbankan. Edisi Revisi. Cetakan ke duabelas. PT. RajaGrafindo Persada. Jakarta.

Mulyadi. 2014. Sistem Akuntansi. Salemba Empat. Jakarta.

Undang-Undang Republik Indonesia Nomor 10 tahun 1998 tentang perbankan. 10 November 1998. Lembaran Negara Tahun 1998 Nomor 182. Jakarta.

Undang-Undang Republik Indonesia Nomor 20 tahun 2008 tentang Usaha Mikro, Kecil, Menengah. 4 Juli 2008. Lembaran Negara Republik Indonesia Tahun 2008 Nomor 4866. Jakarta.

Sugiyono. 2013. Metodologi penelitian kuantitatif, kualitatif dan R\&D. Alfabeta. Bandung. Tuanakotta, T.M. 2014. Audit Berbasis ISA. Salemba Empat. Jakarta. 